\title{
Spatial distribution of malaria in Warri metropolis
}

\author{
S. I. Efe*, C. O. Ojoh \\ Department of Geography and Regional Planning Delta State University, Abraka, Nigeria \\ Email: "efesundayighovie@yahoo.com, collinsojoh@yahoo.com
}

Received 28 April 2013; revised 27 May 2013; accepted 10 June 2013

Copyright (C) 2013 S. I. Efe, C. O. Ojoh. This is an open access article distributed under the Creative Commons Attribution License, which permits unrestricted use, distribution, and reproduction in any medium, provided the original work is properly cited.

\begin{abstract}
This study examined the spatial distribution of malaria in Warri metropolis. To achieve this, data were generated from medical archival records from hospitals in Warri metropolis. The medical records contain recorded cases by place of diagnosis in 2011 . The data were analysed by using ANOVA to ascertain the spatial differences in the spread of malaria in the metropolis. The result revealed that malaria is at its peak in June and minimal in September owing to the heavy floods in June. It was observed that there is a variation in the prevalence of malaria in the metropolis which is significantly high in area of Okumagba layout, Jakpa, Airport road, Pessu market, Warri main market, and Igbudu market. However, the prevalence of malaria in Warri is significantly different from the prevalence of malaria in Uvwie and Udu. It is anticipated that an increase in malaria is attributed to water bodies, thus, it is recommended that vulnerability mapping should be carried out to identify areas prone to malaria.
\end{abstract}

Keywords: Component; Formatting; Style; Styling; Insert

\section{INTRODUCTION}

Thousands of people are currently living in areas where the malaria vectors are present and circumstances are suitable for parasite development [1]. Tropical zones like sub-Saharan Africa are amenable to high endemic stability, and strongly anthropophilic mosquitoes in many of these areas make malaria transmission very effective [2]. Landscape epidemiology recognizies that disease does not occur sporadically across the landscape; rather there are physical characteristics of a place such as elevation, temperature, and vegetation that contribute to disease expression [3].

Malaria transmission, however, is a complex interac-

"Corresponding author. tion of many factors, including not only vector and parasite densities and behaviour, but also land-use change [4], public health control measures [5-7], human migration [8,9], and drug resistance [10]. The risk of transmission can vary from one geographical area to another and in the same geographical area from one village to another [11]. Distance to breeding sites [12,13] and type of houses are local environmental factors frequently associated with high mosquito density. The location of people and houses within the metropolis with respect to breeding sites as well as randomness, affect the distribution of individual cases at the lowest scale. According to the [14], malaria kills over one million people each year, while 300 to 500 million people are suffering from chronic malaria around the world. This is one of the most common and serious diseases in our time. The difficulty in diagnosis is one of many reasons why the actual figures are expected to be much higher. The death toll is predicted to double in the next 20 years if no new control measures are developed [15]. Adding to the scenario are the anthropogenic changes in our environment. Members of the Anopheles genus are adequate breeders and therefore require rainfall for the production of habitats with suitable level of surface water [16], the eggs are deposited in pools [17] shortly after rainfall [18] and resulting larvae develops in the aquatic environment [19] (see Figure 1).

Mosquito-borne disease transmission is climate sensitive for several reasons; mosquitoes require standing water to breed, and a warm ambient temperature is critical to adult feeding behaviour and mortality, the rate of larval development, and speed of virus replication [20,21] (see Figure 1). If the climate is too cold, viral development is slow and mosquitoes are unlikely to survive long enough to become infectious. Although a suitable climate is necessary for disease transmission, other factors are needed for an epidemic to take place, including a source of infection, vector populations, and a susceptible human population.

In Warri metropolis, most of the natural drains have been closed and the constructed drains are blocked with litters of garbage, hence making areas like Okumagba 


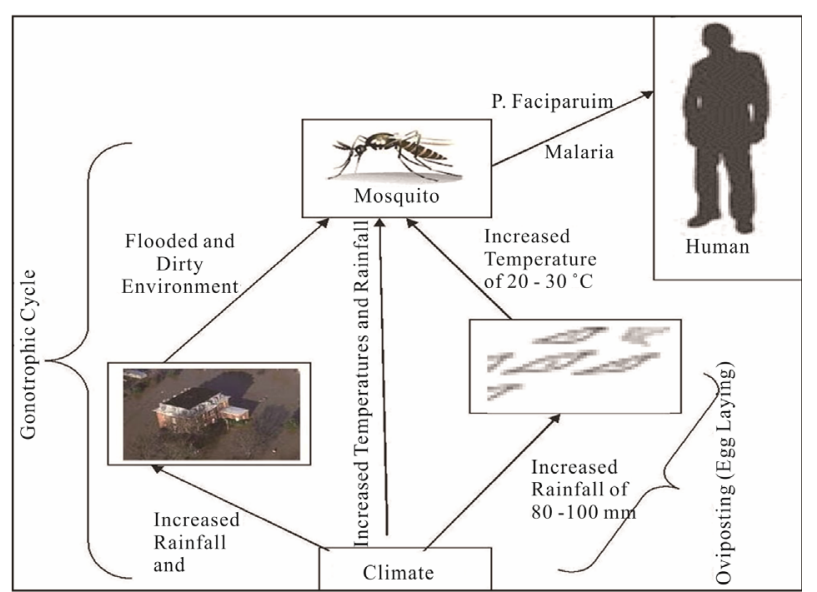

Figure 1. Dynamics of mosquito development; source: [17].

Avenue, Airport road, Makiava areas etc. experience flood; which in turn results in breeding grounds for mosquitoes. The people are vulnerable to mosquito bite resulting in malaria because most of the houses are within the fringes of water bodies, farm gardens and tall grasses as well as within flight distance from their respective breeding habitats. At the same time, malaria transmission intensity varies at different spatial scales.

The location of people and houses within the metropolis with respect to breeding sites as well as randomness, affect the distribution of individual cases at the lowest scale. There have been several attempts to define the global and national distributions of malaria. Common to all previous attempts at mapping malaria risk is that they derive from a combination of expert opinion, limited data and the use of crude geographical and climate isolines. None has a clear and reproducible numerical definition: consequently, their comparative value becomes limited. Consequently, this paper examines the spatial distribution of malaria in Warri metropolis. This research is geared to proffer possible suggestion towards policies implementation to reduce the risk of malaria.

\section{STUDY AREA}

Warri metropolis is located between latitudes $5^{\circ} 30^{1} \mathrm{~N}$ and $5^{\circ} 35^{\circ} \mathrm{N}$ and Longitudes $5^{\circ} 29^{1} \mathrm{E}$ and $5^{\circ} 48^{1} \mathrm{E}$. Warri metropolis is made up of Warri South, Udu and Uvwie Local Government areas. The area is characterized by hydromorphic soils, which is a mixture of course alluvial and colluvium deposits [22]. The rocks are of sedimentary rock types with sand to a top layer (4 - $6 \mathrm{~m}$ ) which is followed by a thick (up to $17 \mathrm{~m}$ ) layer of silt and becoming coarse and pebbly at depth below. The area is characterized by tropical equatorial climate with mean annual temperature of $27.4^{\circ} \mathrm{C}$ and rainfall amount of $275.21 \mathrm{~mm}$.

Rainfall period ranges from January-December, with the minimum value of $20.4 \mathrm{~mm}$ in January and over $499.1 \mathrm{~mm}$ in September [23]. The temperature of $27.4^{\circ} \mathrm{C}$ enhances the transmission of malaria which is caused plasmodium falciparum which requires a minimum temperature of $19^{\circ} \mathrm{C}$ [24]. Furthermore, its soil and low relief feature results in water stagnating on the ground surface which act as breeding ground for mosquitoes causing malaria.

The areal expansion of Warri metropolis is now over 100 sqr. km [22] with a population that has grown from 19,526 in $1933,55,256$ in $1963,280,000$ in 1980 , 500,000 in 1991 to 536,023 in 2006 having a high population density that is concentrated in the core areas of the city. These areas include; Warri-Sapele road, Agbassa, Okere, Okumgba Avenue, Igbudu, Iyara, Jakpa and Airport road, P.T.I. road, Udu and Ekpan. This has resulted to an increase in the incident of anthropogenic activities in these areas.

\section{CONCEPTUAL ISSUES}

The success of spatial distribution of disease requires accurate information on vector biology and ecology, malaria transmission and epidemiology, in relationship to local environmental conditions, and a good stratification of control areas with respect to time and space [25]. Epidemiology concept is concerned with the study of the occurrence, distribution, determinants of diseases and injuries in human populations. Thus, it concerns with the types and frequencies of illnesses, injuries, and other health-related conditions or problems in groups of people and with the factors that influence their distribution and to discover the factors essential for diseases to occur within groups. Furthermore, finding the best methods to reduce or prevent those factors and other conditions detrimental to the health of communities [14]. Malaria control is based on the three main functions which epidemiologists perform, more or less successfully, namely, in order of increasing difficulty and uncertainty:

1) To describe and measure the distribution of disease, e.g. who gets malaria, how much of it, when and where?

2) To explain that distribution by its determinant factors: biological, environmental, social, behavioural and economic.

3) To predict the changes expected in that distribution from human interventions, in particular from control measures.

These three epidemiological functions constitute important inputs into the planning of malaria control, with the aim of adopting the control strategy to the epidemiological situation. Within an epidemiology approach, the diverse set of factors associated with malaria is considered in the context of Epidemiology Triangle, linking the environment with disease transmission and health. The epidemiologic triangle consists of three components, with the Agent at the top point and the Host and the Environment at the other two points of the triangle. Each 
component must be analysed and understood to comprehend and predict patterns of disease (see Figure 2).

The complex nature of the host-vector-agent characteristics of the disease in relationship to the environment has been recognised as the primary cause of malaria illness over the years [26]. Changes in any component will alter the existing equilibrium to increase or decrease the frequency of a disease. In a steady state of the triangle, each leg of the component is affecting and being affected by the other components. Any influence among the triangle relationship will impact the epidemics of vectorborne infectious disease.

\section{MATERIALS AND METHOD}

The data utilized for this study was generated from the archives of hospitals medical records of malaria in-patient and out-patient diagnosis in Warri metropolis. The data contains recorded cases by place of diagnosis which was obtained from the two (2) central hospitals (Central Hospital, Warri and central Hospital, Ekpan) and one (1) renowned hospital each from the three (3) local Government Areas; (Numa Clinic, Odion Road) Warri, (Twins Clinic, Udu Road) Udu and (NNPC Clinic, Ekpan) Uvwie respectively. The choice of these three hospitals was for data consistency. The medical records contain the number of patients treated for malaria in 2011. ANOVA was used to ascertain the spatial variation of malaria in Warri metropolis.

Malaria is at its peak in the month of June and minimal in September (see Table 1). It is worth noting that the mosquito breeds well in flooded environment. During the month of June, Warri metropolis is heavily flooded. Malaria transmission in the Warri metropolis is characterized by substantial inter-monthly variation. Minakaw [27] asserted that the wet season presents favourable environmental conditions that enhance mosquito breeding and survival.

Table 2 reveals that in Warri metropolis the high

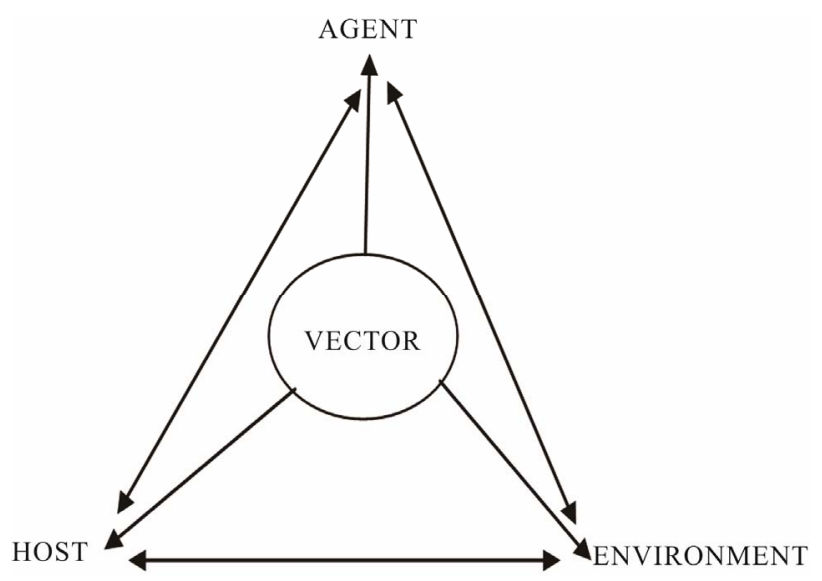

Figure 2. Agent-Host-Environment interaction; source: [26]. prevalence of malaria are found in areas of Okumagba layout, Jakpa, Airport road, Pessu market, Warri main market, and Igbudu market (see Figure 3). However, the low malaria prevalence area represented by SPDC, Edjeba, Ubeji, Ugbomro, DBS express, G.R.A at Warri and Effurun. Succinctly, the highest episode of malaria prevalence was recorded in Okumagba layout areas (see Table 2). The increased malaria prevalence is attributed to increase flooding which results from increased rainfall there by creating breeding sites for mosquitos.

Table 3 shows a calculated $\mathrm{F}$ of 7.857 at $\mathrm{P}<0.05$ and thus, the model is significant. Therefore, there is a statistically significant difference in the spatial spread of malaria between the three locations (Warri, Uvwie and Udu) that are being compared. Looking at the Sig. column in the Turkey's post hoc test, there are values lesser than 0.05 (see Table 4). However, there are two values that are 0.042 and 0.026 . These values correspond with the comparison between the prevalence of malaria in Udu and Warri, and malaria prevalence in Warri and Uvwie conditions. Conclusively, the prevalence of malaria in Warri is significantly different from the prevalence of malaria in Uvwie and Udu. However, the prevalence of malaria in Uvwie and Udu are not significantly different from one another. This finding corroborates with study of spatial and temporal distribution of falciparum malaria in China by Lin [28] showing that stable falciparum malaria transmission occurs in the bordering region of Yunnan and the hilly-forested.

\section{MALARIA MANAGEMENT MEASURES}

Integrated Vector Management encourages a multi-disease control approach, integration with other disease control measures and the considered and systematic application of a range of interventions, often in combination and synergistically (WHO, 2004). This management serves to maximize cost effectiveness and extend the useful life of insecticides and drugs by reducing the selection pressure for resistance development. Integrated Vector Management harnesses precise scientific knowledge of the vector ecosystem and its inter-relationship to human ecosystems to address the following issues in more environmentally sustainable ways. However, environmental modification has been used successfully to destroy either vector or reservoir host habitat, particularly at the fringes of disease transmission. Although destructive locally, careful targeting can minimize environmental impacts.

Furthermore, efforts to address the issue of malaria resulting from environmental changes have to be strengthened. Preventive public health could also be initiated by warning and the education of public and local communities to conduct relevant health promotion cam- 
paigns, and to change behaviours such as increasing awareness of the potential risks of climate variation on health, health safety warnings for travellers to high risk regions, and promoting self-protection measures, such as wearing long sleeve clothing or using insect repellent to prevent mosquitoes bites, and using mosquito nets at night and screen doors and windows where appropriate. In addition, hospitals and doctors should prepare for extra health

Table 1. Monthly malaria distribution in Warri metropolis in 2011.

\begin{tabular}{|c|c|c|c|c|c|c|c|c|c|c|c|c|c|}
\hline Location & Jan & Feb & March & April & May & June & July & Aug & Sept & Oct & Nov & Dec & Total \\
\hline A & 132 & 118 & 128 & 124 & 143 & 229 & 178 & 170 & 109 & 149 & 141 & 113 & 1734 \\
\hline B & 123 & 103 & 115 & 107 & 129 & 222 & 173 & 164 & 101 & 145 & 130 & 108 & 1620 \\
\hline $\mathrm{C}$ & 122 & 109 & 116 & 119 & 132 & 223 & 171 & 158 & 106 & 141 & 132 & 101 & 1630 \\
\hline D & 115 & 105 & 96 & 112 & 120 & 215 & 157 & 163 & 93 & 145 & 117 & 112 & 1550 \\
\hline $\mathrm{E}$ & 90 & 94 & 111 & 86 & 122 & 211 & 151 & 140 & 57 & 131 & 93 & 86 & 1372 \\
\hline Total & 582 & 529 & 566 & 548 & 646 & 1100 & 830 & 795 & 466 & 711 & 613 & 520 & 7906 \\
\hline Prevalence & 1.09 & 0.99 & 1.06 & 1.02 & 1.21 & 2.05 & 1.55 & 1.48 & 0.87 & 1.33 & 1.14 & 0.97 & 14.76 \\
\hline
\end{tabular}

Source: Hospital records and Field work, 2011; A = Central Hospital Warri, B = General Hospital, Ekpan, C = Numa Clinic, Odion Road, Warri, D = Twins Clinic, Udu, E = NNPC Clinic, Ekpan.

Table 2. Malaria distribution in Warri metropolis.

\begin{tabular}{|c|c|c|c|c|c|c|c|}
\hline $\mathbf{S} / \mathbf{N}$ & Neighbourhoods & Total Malaria Cases & $\mathbf{A}$ & B & $\mathbf{C}$ & D & $\mathbf{E}$ \\
\hline 1 & Jakpa Road & 531 & 29 & 416 & 3 & 1 & 82 \\
\hline 2 & Okumagba L/O & 826 & 498 & 187 & 48 & 38 & 55 \\
\hline 3 & Airport Road & 499 & 199 & 226 & 22 & 13 & 39 \\
\hline 4 & Upper/Lower Eredjuwa & 311 & 267 & 9 & 31 & 3 & 1 \\
\hline 5 & Enerhen/Udu Rd. & 200 & 91 & 44 & 37 & 17 & 11 \\
\hline 6 & DSC Town & 349 & 97 & 120 & 16 & 101 & 15 \\
\hline 7 & GRA Warri & 69 & 43 & 6 & 16 & 1 & 3 \\
\hline 8 & GRA Effurun & 143 & 11 & 93 & 3 & 9 & 27 \\
\hline 9 & PTI road & 343 & 181 & 117 & 13 & 27 & 5 \\
\hline 10 & NNPC & 210 & 94 & 55 & 11 & 9 & 41 \\
\hline 11 & SPDC & 62 & 33 & 17 & 8 & 3 & 1 \\
\hline 12 & DBS Express rd & 131 & 28 & 82 & 16 & 1 & 4 \\
\hline 13 & Effurun Mkt & 296 & 83 & 157 & 32 & 15 & 9 \\
\hline 14 & Warri Mkt & 495 & 394 & 5 & 89 & 1 & 6 \\
\hline 15 & Pessu Mkt & 571 & 370 & 183 & 17 & 0 & 1 \\
\hline 16 & Igbudu Mkt & 498 & 303 & 142 & 51 & 2 & 0 \\
\hline 17 & Edjeba & 131 & 66 & 30 & 5 & 3 & 27 \\
\hline 18 & Ugborikoko & 421 & 223 & 193 & 2 & 1 & 2 \\
\hline 19 & Enerhen Village & 298 & 154 & 101 & 34 & 6 & 3 \\
\hline 20 & Ekpan village & 355 & 210 & 142 & 0 & 3 & 0 \\
\hline 21 & Osubi & 212 & 85 & 123 & 2 & 2 & 0 \\
\hline 22 & Ubeji & 142 & 49 & 77 & 13 & 2 & 1 \\
\hline 23 & Aladja & 327 & 36 & 188 & 38 & 64 & 1 \\
\hline 24 & Orhuworun & 298 & 104 & 99 & 27 & 66 & 2 \\
\hline \multirow[t]{2}{*}{25} & Ugbomro & 188 & 50 & 102 & 2 & 33 & 1 \\
\hline & Total & 7906 & 3698 & 2914 & 536 & 421 & 337 \\
\hline
\end{tabular}

Source: Hospital records, 2011. 
Table 3. ANOVA on the spatial spread of malaria.

\begin{tabular}{cccccc}
\hline & Sum of Squares & df & Mean Square & F & Sig. \\
\hline Between Groups & $\mathbf{4 3 1 4 0 9 . 5 5 6}$ & $\mathbf{2}$ & $\mathbf{2 1 5 7 0 4 . 7 7 8}$ & $\mathbf{7 . 8 5 7}$ & $\mathbf{0 . 0 2 1}$ \\
Within Groups & $\mathbf{1 6 4 7 2 9 . 3 3 3}$ & $\mathbf{6}$ & $\mathbf{2 7 4 5 4 . 8 8 9}$ & & \\
Total & $\mathbf{5 9 6 1 3 8 . 8 8 9}$ & $\mathbf{8}$ & & & \\
\hline
\end{tabular}

Table 4. Post Hoc test.

\begin{tabular}{|c|c|c|c|c|c|c|}
\hline \multirow{2}{*}{ (I) Locations } & \multirow{2}{*}{ (J) Locations } & \multirow{2}{*}{ Mean Difference (I-J) } & \multirow{2}{*}{ Std. Error } & \multirow{2}{*}{ Sig. } & \multicolumn{2}{|c|}{ 95\% Confidence Interval } \\
\hline & & & & & Lower Bound & Upper Bound \\
\hline \multirow{2}{*}{$1 \mathrm{Udu}$} & 2 Uvwie & 53.000 & 135.290 & 0.920 & -362.11 & 468.11 \\
\hline & 3 Warri & -435.667 & 135.290 & 0.042 & -850.77 & -20.56 \\
\hline \multirow{2}{*}{2 Uvwie } & $1 \mathrm{Udu}$ & -53.000 & 135.290 & 0.920 & -468.11 & 362.11 \\
\hline & 3 Warri & -488.667 & 135.290 & 0.026 & -903.77 & -73.56 \\
\hline \multirow{2}{*}{3 Warri } & $1 \mathrm{Udu}$ & 435.667 & 135.290 & 0.042 & 20.56 & 850.77 \\
\hline & 2 Uvwie & 488.667 & 135.290 & 0.026 & 73.56 & 903.77 \\
\hline
\end{tabular}

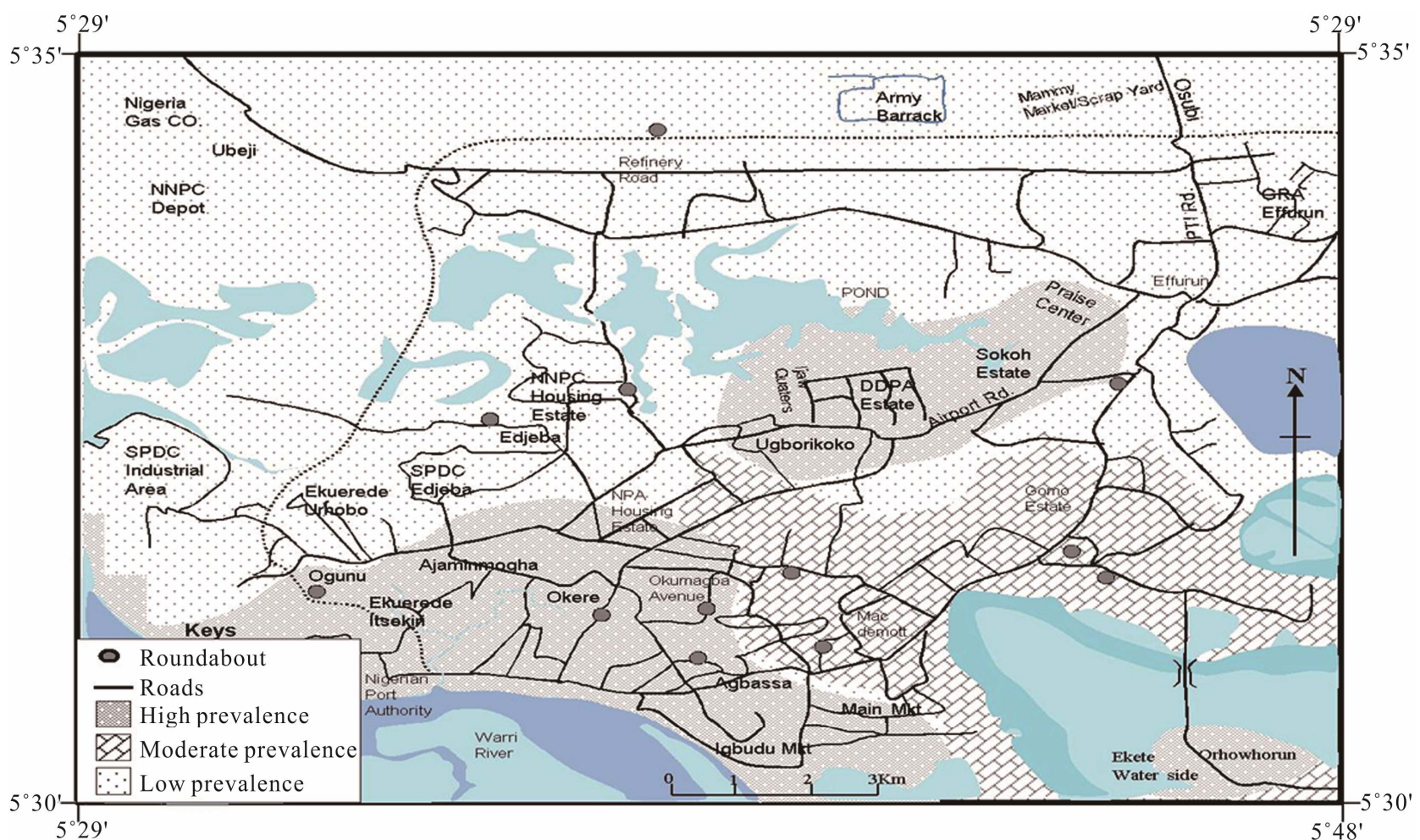

Figure 3. Spatial distribution of malaria in Warri metropolis.

burdens from malaria disease.

\section{CONCLUSION}

Findings of this study demonstrate increased exposure to malaria in areas near water bodies serving as mosquito vector breeding sites. Malaria transmission in the Warri metropolis is characterized by substantial inter-monthly variation. The prevalence of malaria is high in Okumagba layout, Jakpa, Airport road, Pessu market, Warri main market, and Igbudu market areas of the metropolis. Succinctly, there is a significant difference in the prevalence of malaria in Warri metropolis. These findings may be useful for the planning of malaria control activities, as they may induce the design and implementation of more reliable malaria policy and intervention in the region. It is therefore recommended that vulnerable mapping should be carried out to identify areas in which malaria is likely to invade. Entomological and parasitological surveillance 
should be undertaken in vulnerable areas. Research on integrated malaria control should be enhanced with the intent of developing cost effective malaria control strategies.

\section{REFERENCES}

[1] Martens, P. and Hall, L. (2000) Malaria on the move: Human population movement and its impact on malaria transmission. Emerging Infectious Diseases, 6, 7-13. doi:10.3201/eid0602.000202

[2] National Center for Infectious Diseases. (2004) Anopheles mosquitoes, malaria.

[3] Moore, C. (2008) Interdisciplinary research in the ecology of vector-borne diseases: Opportunities and needs. Journal of Vector Ecology, 33, 218-224. doi:10.3376/1081-1710-33.2.218

[4] Lindblade, K.A., Walker, E.D., Onapa, A.W., Katungu, J. and Wilson, M.L. (2000) Land use change alters malaria transmission parameters by modifying temperature in a highland \& area of Uganda. Tropical Medicine and International Health, 5, 263-274. doi:10.1046/j.1365-3156.2000.00551.x

[5] Alonso, P.L., Lindsay, S.W., Armstrong, J.R.M., Conteth, M., Hill, A.G., David, P.H., Fegan, G., Defrancisco, A., Hall, A.J. and Shenton, F.C. (1991) The effect of insecticide-treated bed nets on mortality of Gambian children. Lancet, 337, 1499-1502. doi:10.1016/0140-6736(91)93194-E

[6] Snow, R.W., Mungala, V.O., Foster, D. and Marsh, K. (1994) The role of the district hospital in child survival at the Kenyan coast. African Journal of Health Sciences, 1, 11-15.

[7] Binka, F.N., Kubaje, A., Adjuik, M., Williams, L.A., Lengeler, C., Maude, G.H., Armah, G.E., Kajihara, B., Adiamah, J.H. and Smith, P.G. (1996) Impact of permethrin impregnated bednets on child mortality in Kassena Nanakan District, Ghana: A randomized control trial. Tropical Medicine and International Health, 1, 147-154. doi:10.1111/j.1365-3156.1996.tb00020.x

[8] Crowe, S. (1997) Malaria outbreak hits refugees in Tanzania. Lancet, 350, 41. doi:10.1016/S0140-6736(05)66261-7

[9] Martens, P., Kovats, R. and Nijhof, S. (1999) Climate change and future populations at risk of malaria. Global Environmental Change. Part A: Human \& Policy Dimensions, 9, s89-s107. doi:10.1016/S0959-3780(99)00020-5

[10] Snow, R.W., Trape, J.F. and Marsh, K. (2001) The past, present, and future of childhood malaria mortality in Africa. Trends in Parasitology, 17, 593-597. doi:10.1016/S1471-4922(01)02031-1

[11] Mbogo, C.M., Mwangangi, J.M., Nzovu, J., Gu, W., Yan, G., Gunter, J.T., Swalm, C., Keating, J., Regens, J.L., Shililu, J.I., Githure, J.I. and Beier, J.C. (2003) Spatial and temporal heterogeneity of anopheles mosquitoes and Plasmodium falciparum transmission along the Kenyan coast. The American Journal of Tropical Medicine and Hygiene, 68, 734-742.
[12] Cano, J., Descalzo, M.A., Moreno, M., Chen, Z., Nzambo, S., Bobuakasi, L., Buatiche, J.N., Ondo, M., Micha, F. and Benito, A. (2005) Spatial variability in the density, distribution and vectorial capacity of anopheline species in a high transmission village (Equatorial Guinea). $\mathrm{Ma}$ laria Journal, 23, 5-21.

[13] Oesterholt, M.J., Bousema, J.T., Mwerinde, O.K., Harris, C., Lushino, P., Masokoto, A., Mwerinde, H., Mosha, F.W. and Drakeley, C.J. (2006) Spatial and temporal variation in malaria transmission in a low endemicity area in northern Tanzania. Malaria Journal, 3, 5-98.

[14] WHO (2004) Global strategic framework for integrated vector management, WHO, Geneva, Switzerland. WHO Document. 10, 1-12.

[15] Chapman, C.A., Gillespie, T.R. and Goldberg, T.L. (2005) Primates and the ecology of their infectious disease: How will anthropogenic change affect host parasite interactions. Evolutionary Anthropology, 14, 134-144. doi:10.1002/evan.20068

[16] Grover-Kopec, E.K., Blumenthal, M.B., Ceccato, P., Dinku, T., Omumbo, J.A. and Connor, S.J. (2006) Web-based climate information resources for malaria control in Africa. Malaria Journal, 5, 38. doi:10.1186/1475-2875-5-38

[17] Hoshen, M.B. and Morse, A.P. (2004) A weather driven model of malaria transmission. Malaria Journal, 3, 32. doi:10.1186/1475-2875-3-32

[18] Bayoh, M.N. and Lindsay, S.W. (2004) Temperaturerelated duration of aquatic stages of the Afrotropical malaria vector mosquito. Anopheles gambiae in the laboratory. Medical and Veterinary Entomology, 18, 174-179. doi:10.1111/j.0269-283X.2004.00495.X

[19] Lindsay, S.W. and Martens, W.J.M. (1998) Malaria in the African highlands: Past, present and future. Bulletin of the World Health Organisation, 76, 33-45.

[20] Gubler, D.J. (1998) Dengue and dengue hemorrhagic fever. Clinical Microbiology Reviews, 11, 480-496.

[21] Gubler, D.J. (2001) Human arbovirus infectious worldwide. Annals of the NewYork Academy of Sciences, 951, 13-24. doi:10.1111/j.1749-6632.2001.tb02681.x

[22] Efe, S.I. (2002) Urban warming in Nigeria cities: The case of Warri metropolis. African Journal of Environmental Studies, 3, 160-168.

[23] Efe, S.I. and Ojoh, C.O. (2011) Climate variability and commercial activities in Warri metropolis, Nigeria. Journal of Social and Management Sciences, 6, 61-68.

[24] Sharma, V.P. and Bos, R. (2003) Determinants of malaria in South-Asia. In: Casman, E. and Dowlatabadi, H., Eds., The Contextual Determinants of Malaria, Resources for the Future, Washington DC.

[25] Toure, Y.T., Oduola, A.M. and Morel, C.M. (2004) The anopheles gambiae genome: Next steps for malaria vector control. Trends in Parasitology, 20, 142-149. doi:10.1016/j.pt.2004.01.008

[26] Sutherst, R.W. (2004) Global change and human vulnerability to vector-borne diseases. Clinical Microbiology Reviews, 17, 136-173. doi:10.1128/CMR.17.1.136-173.2004

[27] Minakaw, N., Sonye, G., Mogi, M., Githeko, A. and Yan, 
G. (2001) The effect of climate factors on the distribution and abundance of malaria vectors in Kenya. Journal of Medical Entomology, 39, 833-841.

doi:10.1603/0022-2585-39.6.833
[28] Lin, H., Lu, L., Tian, L., Zhou, S., Wu, H., Bi, Y., Ho, S.C. and Liu, Q. (2009) Spatial and temporal distribution of falciparum malaria in China. Malaria Journal, 8, 8-13. 